\title{
A systematic study of the genus Pseudopentameris (Arundinoideae: Poaceae)
}

\author{
N.P. BARKER*
}

Keywords: Arundineae. Arundinoideae, conservation, leaf anatomy, phenetics, phylogenetics. Poaceae, Pseudopentameris, systematics

\section{ABSTRACT}

The genus Pseudopentameris Conert is examined morphologically and anatomically. A phenetic study of the morphologically variable species $P$, macrantha indicates that two taxa should be recognised. One of these. $P$. caespitosa N.P. Barker. is described as new. In addition, the study supports the inclusion of Pentameris obtusifolia in Pseudopentameris. The genus Pseudopentameris is re-delimited to accommodate the new taxa. and a key to species is provided. Details of the cytology. phylogeny and conservation status of taxa in the genus are also discussed.

\section{UITTREKSEL}

Die genus Pseudopentameris Conen word morfologies en anatomies ondersoek. 'n Fenetiese ondersoek van die variërende spesie P. macrantha toon dat twee taksons erken moet word. Een van hulle. P. caespitosa N.P. Barker. word as nuut beskryf. Verder ondersteun die ondersoek die insluiting van Pentameris obtusifolia in Pseudopentameris. Die genus Pseudopentameris word heromgrens om die nuwe taksons te huisves, en 'n sleutel tot die spesies word verskaf. Besonderhede van die sitologie, tilogenie en bewaringstatus van taksons in die genus word ook bespreek.

\section{INTRODUCTION}

The genus Pseudopentameris Conert is endemic to the lowland fynbos of the southwestern Cape Province. South Africa. This genus was created by Conert (1971), who thought that two species of the genus Danthonia DC., $D$. macrantha Schrad. and D. brachyphylla Stapf, merited recognition as a separate genus. This new genus was characterised by unusually large spikelets which, while similar to both those of Pentameris P. Beauv. and Danthonia, differed in having many-nerved glumes. The nature of the fruit of these two species also set them apart.

Studies of the leaf anatomy (discussed below) provided further evidence of their singularity (De Wet 1956, 1960; Ellis 1985a). Ellis (1985b) observed that the leaf anatomy of the taxon he called Pentameris sp. nov., bore a strong resemblance to the anatomy of the two known species of Pseudopentameris, and postulated a hybrid origin for this species. Additional studies on the fruit morphology (Barker 1986, 1989, 1993) and leaf anatomy (presented below) also suggested that this unusual species has close affinities with the other species of Pseudopentameris. Because of the nomenclatural confusion surrounding this taxon (see 1. Pseudopentameris obtusifolia below), past studies have referred to it by a number of names. Barker (1989) and Ellis (1985b) referred to it as Pentameris sp. nov. whereas Linder \& Ellis (1990) refer to it as Pentameris squarrosa Stapf. Some herharia (in particular PRE and STE) misapplied this name to the taxon now known as Pentameris oerophila N.P. Barker (1993), whereas BOL has used the synonym Pentameris squarrosa Stapf.

\footnotetext{
* Department of Botany. University of Cape Town. Private Bag. Ronde bosch $77(x)$. Present address: Department of Bexany. University of the Western Cape, Private Bag X17. Bellville 7535

Email: nigel (abotany.urcic. $z a$

MS. received: 1994-(19)-27.
}

This study encapsulates all these observations, and documents the anatomical and morphological variation within the genus, and presents the relevant nomenclatural modifications that are required as a result of these observations.

\section{MORPHOLOGY}

Pseudopentameris is unusual in having two species ( $P$. macrantha and $P$. obtusifolia) with aerial stems that possess the anatomy of a rhizome (H.P. Linder unpublished). Until the anatomy and homology of these structures is better understood. the term 'stem' is used, as it serves to differentiate this structure from below-ground rhizomes and the annually produced flowering culm.

These stems are often branched, and the annual flowering culms are produced from their apical buds. Subsequent shoot growth takes place from what Linder \& Ellis (1990) term caulescent innovation buds on the stems, which results in branched stems. This branching can lead to a shrub-like growth form in older plants. This type of growth form has also been described in some species of Pentameris (Barker 1993). In Pseudopentameris obtusifolia these branched aerial stems are scandent, spreading out from the base of the plant, over and between the other vegetation. Linder \& Ellis (1990) illustrate this species (named in their work as $P$. squarrosa) and consider its unusual growth form to be an adaptation enabling the plant to survive long interfire periods that are characteristic of the fynbos biome. The two species which do not have these stems ( $P$. brachyphylla and $P$ caespitosa sp. nov. described below) produce the annual flowering culm from an underground thizome that can become fibrous or woody in older plants.

In $P$. obtusifolia the stems are covered by the persistent remains of the leaf sheaths. the dead leaf blades being 


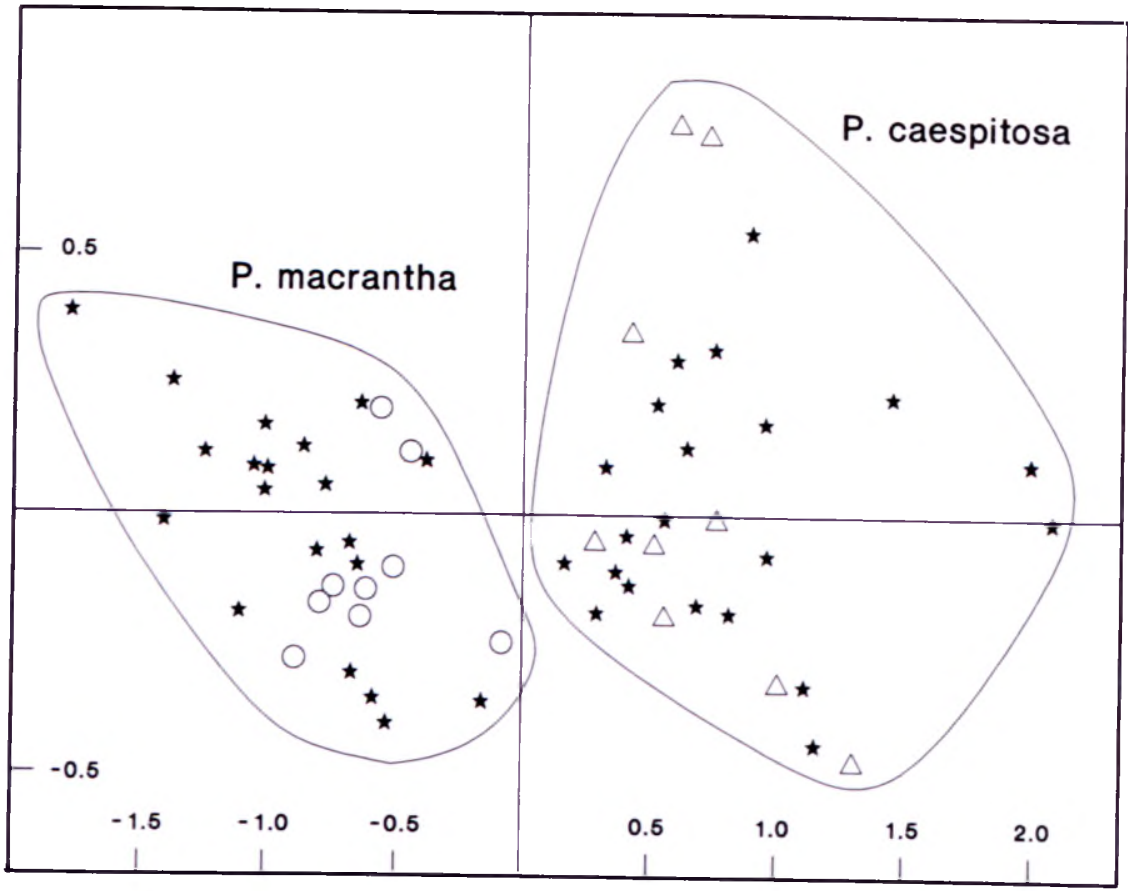

FIGURE 1.-First two axes of Principal Components Analysis (PCA) of 59 specimens matching the previous description of Pseudopentameris macrantha. Specimens measured for six floral characters. First axis: $81.7 \%$ of variation present in data. Second axis: $6.8 \%$. Lines drawn around two groups were placed by eye. Each symbol represents an individual specimen. Specimens with rhizomatous growth form, $P$. macrantha, $\mathrm{O}$; specimens with caespitose growth form, $P$. caespitosa, $\Delta$; specimens with no recorded growth form,

deciduous. In the other species in the genus, the dead leaf blades are persistent, and in P. brachyphylla (Stapf) Conert they curl in a characteristic manner at the base of the plant. The living leaf blades are short, open to rolled and rigid in $P$. obtusifolia, but long, somewhat flexuous and open to rolled in the other species.

The inflorescence is a contracted panicle, which becomes somewhat lax during anthesis and comprises 8-80 spikelets. Spikelet size is variable between the species. The glumes are 3 -nerved in $P$. obtusifolia (the lateral veins are visible only at the base of the glumes) and 5-9-nerved in the other species. The lemmas are variously pubescent, with a geniculate central awn. The lemma lobes are acuminate and variously adnate to the lateral bristle. The palea is bicarinate, bifid at the apex and longer than the lemma body. The lodicules are many-nerved (G.A. Verboom unpublished data), cuneate, glabrous or ciliolate. The latter condition is developed to the extreme in $P$. obtusifolia, which has densely ciliolate lodicules, the cilia being as long as the lodicule bodies.

Each floret has three large anthers (up to $9 \mathrm{~mm}$ ). The ovaries of all taxa possess what Barker (1990, 1994) termed pseudostigmata. These structures have the appearance of stigmatic hairs, and arise from the region between the points of origin of the style branches, although the style branches themselves appear to be absent (or alternatively have stigmata along their entire length, from the apex of the ovary upwards). As the pseudostigmata are easily deciduous, they are seldom observed on mature fruit. Their presence may, however, explain the references by De Wet (1954b) and Tomlinson (1985) to hairs which are decurrent on the inner side of the caryopsis and join over the top of the ovary. A similar description of these structures is given by Chippindall (1955). These features, although not labelled as pseudostigmata, appear in the figures published by Barker $(1986,1990)$. The fruit is a caryopsis (Clayton \& Renvoize 1986), up to $6 \mathrm{~mm}$ long, with a long, canaliculate hilum extending almost the full length of the fruit. The embryo is a quarter to a fifth the length of the fruit (Conert 1971: Barker 1986, 1989, 1990)). The surface of the caryopsis is reticulate (Barker 1986, 1989).

Barker (1990) noted substantial variation in the size of the floral parts in specimens identified as $P$. macrantha. This prompted an additional study in which measurements of six floral characters from 59 specimens were taken, including those examined in the earlier study. The phenetic package NTSYS-pc version 1.4 (Numerical Taxonomy and SYStematics package; Rohlf 1988) was used to perform a Principal Components Analysis (PCA).

The first three principal components (axes) account for $92.9 \%$ of the variation in the data. When the specimens are plotted out on the first two axes (accounting for $88.5 \%$ of the variation), two clusters are apparent (Figure 1). Each cluster contains specimens from a wide geographic area, and the geographic areas of the two clusters overlap extensively. Furthermore, specimens from each cluster have been observed to co-occur. Despite this sympatric distribution, a one-sided T-test showed that the differences in the means of each of the six characters from the two clusters were statistically significant at a $99.9 \%$ confidence interval. Table 1 presents the sample means and standard deviations of these characters in each cluster.

TABLE 1.-Sample means and standard deviations ( $\mathrm{mm}$ ) for six quan titative floral characters of two clusters of specimens correspond ing to $P$. macrantha and $P$. caespitosa. A one-sided T-test shows that differences between means for all characters are significan at $99.9 \%$ confidence interval

\begin{tabular}{|c|c|c|c|c|}
\hline \multirow{2}{*}{ Floral part } & \multicolumn{2}{|c|}{ P. macrantha } & \multicolumn{2}{|c|}{$P$ caespitosd } \\
\hline & Mean & Std dev. & Mean & Std dev. \\
\hline Glume & 37.14 & 5.747 & 46.16 & 5.755 \\
\hline Iemma & 6.43 & 0.884 & 8.80 & 0.772 \\
\hline Awn: base-knee & 8.03 & 1.488 & 13.30 & 2.049 \\
\hline Awn: knee-tip & 14.58 & 2.220 & 23.38 & 4.286 \\
\hline Bristle & $12 . .17$ & 1.594 & 20.52 & 3.024 \\
\hline Palea & 9.75 & 0.967 & 12.98 & 1.185 \\
\hline
\end{tabular}


A character not included in the PCA, but overlaid onto the PCA plot, is that of growth form, as related to the presence of the branching stems. This feature was observed in the field for some of the specimens included in the PCA, and the position in the PCA plot of these specimens is shown in Figure 1 by means of open symbols. As can be seen from Figure 1, each cluster has a specific growth form. The cluster with the smaller floral parts includes specimens with branching stems, whereas the specimens with larger floral parts do not possess stems. These two clusters are considered here to be two species: $P$. macrantha and $P$. caespitosa N.P. Barker sp. nov. Descriptions and details on nomenclature of these two species appear below.

\section{LEAF ANATOMY}

Pseudopentameris has been well examined anatomically by De Wet (1956, 1960), Renvoize (1981), Ellis (1985a), Tomlinson (1985) and Barker (1990). The genus as a whole possesses a sclerophyllous type of arundinoid leaf anatomy (Ellis \& Linder 1992). Ellis (1985a) found minor anatomical differences between $P$. macrantha and $P$. brachyphylla. The anatomy of $P$. obtusifolia is only slightly different from the former two species (Ellis 1985b). All the taxa share characters such as the presence of large, inflated abaxial epidermal cells, dumbbell-shaped silica bodies and the absence of abaxial micro- and macrohairs. This knowledge was supplemented in this study by a Scanning Electron Microscope (SEM) survey of the leaf epidermides of all the species in the genus.

The SEM study of both adaxial and abaxial leaf anatomy was carried out on leaf blade material of nine herbarium specimens of $P$. macrantha, nine specimens of $P$. caespitosa, five specimens of $P$. brachyphylla and 11 specimens of $P$. obtusifolia. Leaf material was mounted on SEM stubs and then coated in gold-palladium. The specimens were examined using an ISI-SX-25 Scanning Electron Microscope.

The abaxial epidermis of all specimens examined lacked both microhairs and macrohairs and, as noted by Ellis (1985a), the abaxial epidermides of all the species are almost indistinguishable. However, occasional needlelike prickles were observed. Figure $2 \mathrm{~A}$ illustrates the abaxial epidermis of $P$. obtusifolia.

The adaxial epidermides of $P$. macrantha, $P$ caespitosa and $P$. brachyphylla were almost identical (Figure 2B, C), but the epidermis of $P$. obtusifolia differed, in that it had a denser distribution of prickles (Figure 2D). In all the
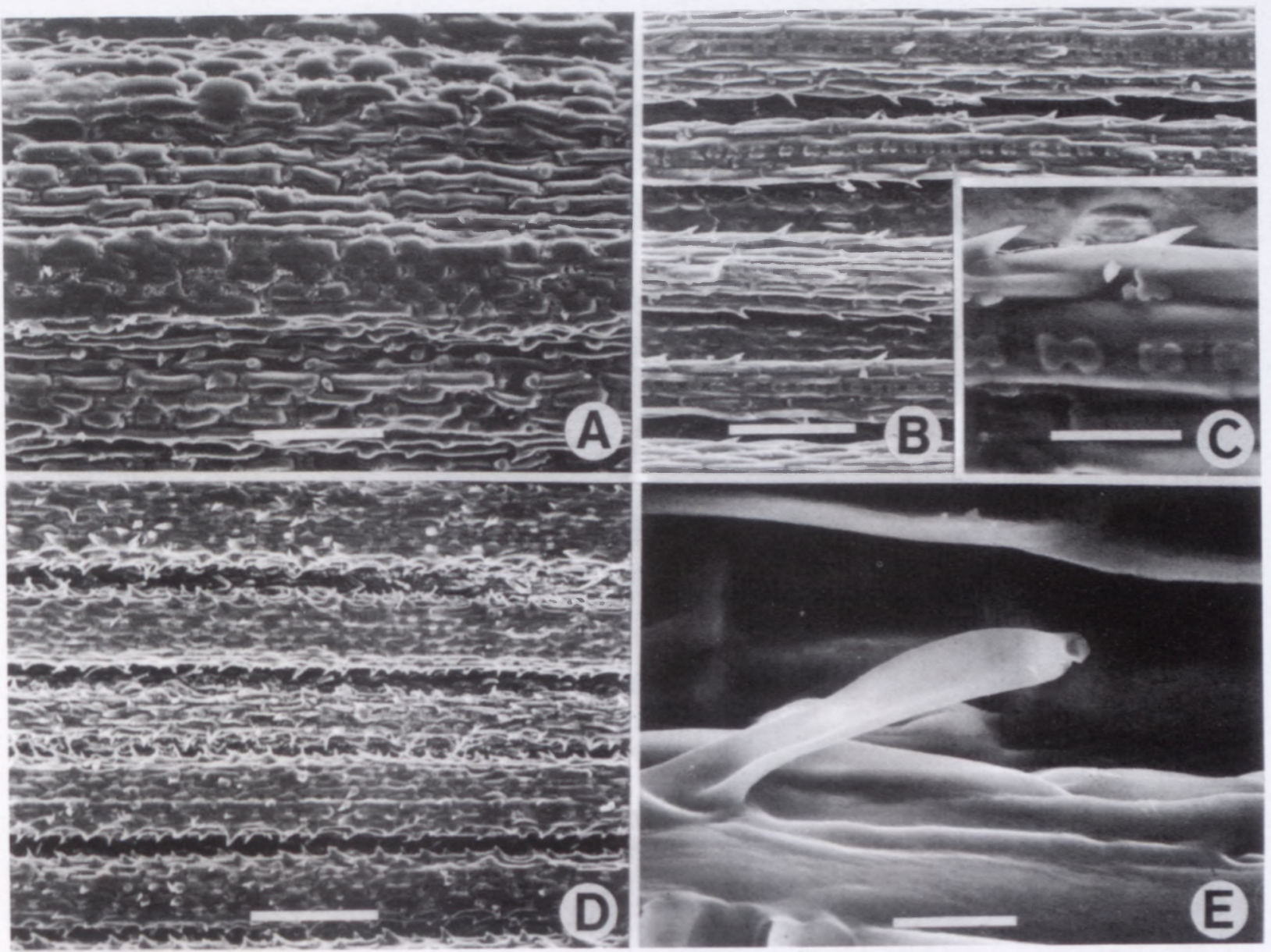

FIGURE 2.- Leaf blade SEM of Pseudopentameris. A, D, P. obtusifolia, Ellis 2342: A, abaxial epidermis showing large inflated epidermal cells and small prickles; D, deeply ribbed adaxial epidermis heavily adorned with prickles. B, P. brachyphylla, Boucher $357 a$, adaxial epidermis showing open furrows and ribs with prickles. C, E, P. macrantha, Ellis 2515: C, adaxial prickles, note also dumbbell-shaped silica bodies; E, microhair from adaxial epidermis, note minute apical cell. Scale bars: A, $225 \mu \mathrm{m} ; \mathrm{B}, 240 \mu \mathrm{m}$; C, $115 \mu \mathrm{m} ; \mathrm{D}, 325 \mu \mathrm{m} ; \mathrm{E}, 17 \mu \mathrm{m}$. 
species, the prickles are needle-like and angled almost parallel to the epidermis. These prickles appear to be modifications of the epidermal cell surface (shown magnified in Figure $2 \mathrm{C}$ ). These prickles are unlike those found in Pentameris (Barker 1993), Pentaschistis (Ellis \& Linder 1992) and at least one species of Merxmuellera (Barker \& Ellis 1991). The prickles of these latter taxa are slightly inflated basally, variable in length but longer than in Pseudopentameris, and protrude away from the epidermis.

Microhairs with minute, deflated apical cells were observed at the bottom of the adaxial furrows (Figure 2E). These bicellular microhairs are similar, except in size, to those reported in Pentameris (Barker 1993). Microhair size ranged from $55-67 \mu \mathrm{m}$. with a mean of $64.8 \mu \mathrm{m}$ (five samples), and (unlike in Pentameris) no species level size differences were apparent. No microhairs were observed on the abaxial leaf surface.

The presence, distribution and nature of microhairs in this genus has been a contentious issue. De Wet (1956. 1960) implies that, as Pseudopentameris has a panicoid epidermis, bicellular hairs (microhairs) would be present, presumably on the abaxial surface. In contrast, Renvoize (1981) considered microhairs to be absent, but later he described "long slender papillae, which in a few instances appear to bear the remains of a thin-walled apical cell' which were associated with the adaxial surface (Renvoize 1986). This description matches the structure shown in Figure $2 \mathrm{E}$, and it appears that these papillae are in fact microhairs.

\section{CYTOLOGY}

The cytology of the genus Danthonia was examined by De Wet $(1953,1954 a, b)$, who was of the opinion that the base chromosome number of this group is $x=6$. The subsequent division of the genus Danthonia resulted in limited cytological knowledge for each of the segregate genera. Additional research by Spies \& Du Plessis (1988) and Du Plessis \& Spies (1988) has increased cytological knowledge about the Danthonia segregates but no chromosome counts of the species of Pseudopentameris have been published. From analyses of the relationship between stomatal size and chromosome counts. De Wet (1954a) predicted a count of $2 n=24$. This figure is credible, as many of the African arundinoid genera display intraspecific polyploidy (see the study on Chaetobromus by Spies et al. 1990).

\section{CONSERVATION STATUS}

Two species in the genus are mentioned in local conservation texts. Pseudopentameris obtusifolia (under the name of Pentameris obtusifolia) is listed by Hall et al. (1980) as a threatened species, the conservation status of which is given as 'uncertain'. However, owing to the nomenclatural difficulties experienced with this taxon (discussed below and in Barker 1993) and the lack of voucher citations, the exact identity of this taxon is not certain. Pseudopentameris brachyphlla is considered by Bond \& Goldblatt (1984) to be rare, as it is restricted to the Caledon area. Both these species are restricted to relatively small areas at a low to mid altitude. Therefore, although not presently under threat, their narrow habitat range places them in a category that may best be described as 'potentially threatened'.

\section{PHYLOGENETIC RELATIONSHIPS}

The genus Pseudopentameris now contains four species. These species are united by an unusual fruit morphology and the presence of pseudostigmata (described above). This fruit morphology is rare in the southern African Arundineae. The only other arundinoid taxon with a similar fruit type is Chaetobromus Nees, the fruit of which are somewhat smaller, but similar in all other respects except the possession of pseudostigmata (Barker 1994). The close relationship between these two genera is further supported by DNA-based molecular studies (Barker et al. in prep.). As Pseudopentameris has both anatomical and morphological autapomorphies (the presence of inflated abaxial epidermal cells and the presence of the pseudostigmata on the apex of the ovary) the genus is distinct from Chaetobromus, and the two genera ought not to be combined. Autapomorphies for Chaetobromus include spikelets which disarticulate below the glumes and dimorphic florets. In Pseudopentameris, and many other arundinoid genera, the spikelets disarticulate above the glumes. Chaetobromus is the only arundinoid genus which has dimorphic florets: the basal ones are glabrous, the upper ones variously hirsute.

Affinities between Pseudopentameris and other 2-flowered arundinoids. Pentameris and Pentaschistis, have also been postulated (e.g. Ellis 1985b; Ellis \& Linder 1992). Pentameris is presently defined by fruit characters (an achene with an apical crown of hairs; Barker 1993), whereas Pentaschistis, as presently defined, has no obvious autapomorphy, and may include both Pentameris and Prionanthium Desv. (H.P. Linder pers. comm.). While the presence of 2 flowered spikelets may indicate some degree of relationship of Pseudopentameris to these genera, other features such as the sclerophyllous type of arundinoid leaf anatomy suggest that these relationships extend beyond these taxa to genera such as Merxmuellera. The assessment of phylogenetic relationships of Pseudopentameris and other arundinoid taxa therefore needs to be done in the broadest possible context. and should include all taxa and not be restricted to the southem African genera. Such a study is presently under way (H.P. Linder et al. in prep.).

\section{TAXONOMY}

Pseudopentameris Conert in Mitteilungen der Botanischen Staatssammlung. München 10: $3(04$ (1971). Type species: Pseudopentameris macrantha (Schrad.) Conert.

Plants perennial; caespitose, scandent or sometimes branched. Stems 0.4-1.4(-2) m long, woody and persistent or herbaceous from woody base; flowering culms up to $0.8 \mathrm{~m}$ long. Leaves: sheaths appressed to culm. persistent: sheath mouth sometimes auriculate; ligule a fringe of hairs: leaf blades linear, $25-5(0) \mathrm{mm}$ long, rigid or soft. open and that to rolled and rigid. Inflorescence paniculate. lanceolate and somewhat contracted. Spikelets 6-80, laterally compressed, 2-flowered. highly reduced third tloret 


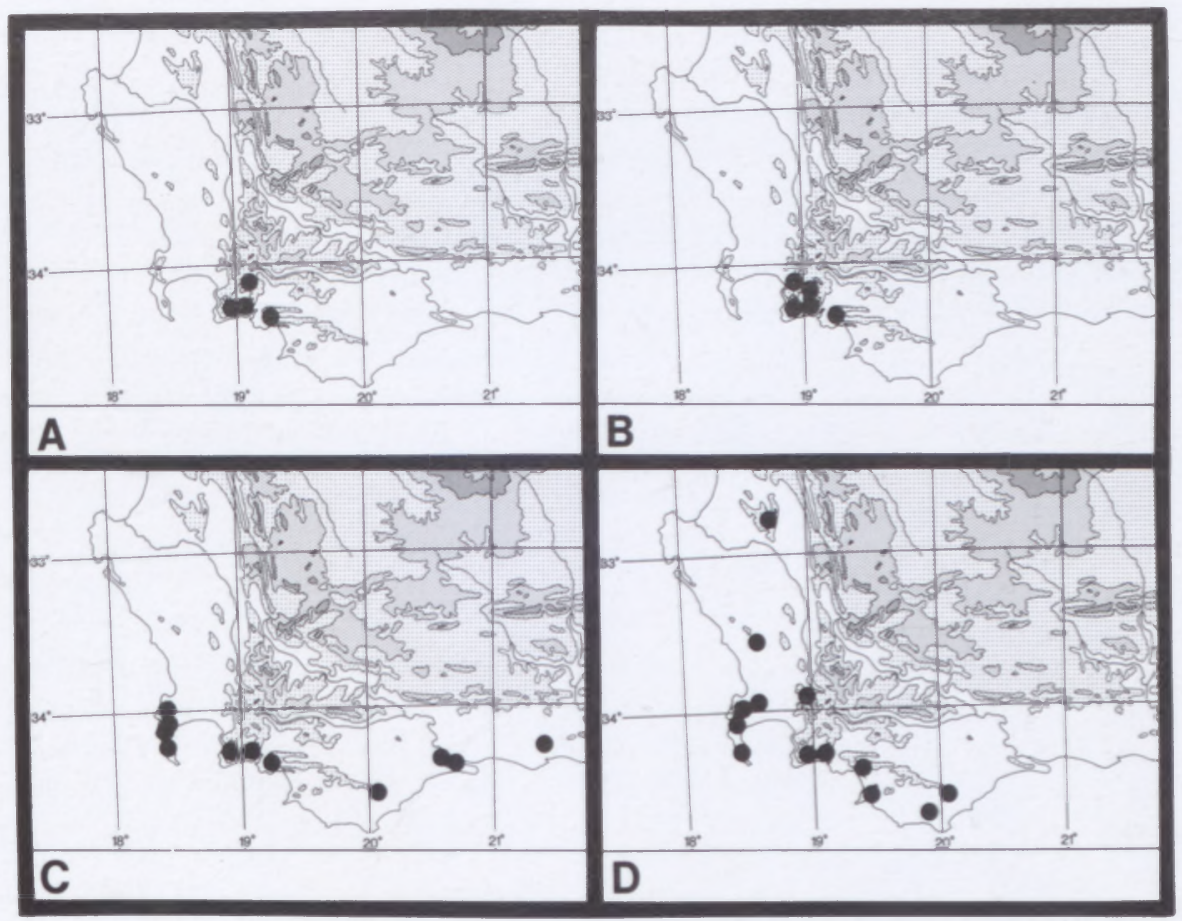

FIGURE 3.-The distribution of Pseudopentameris spp. in the southwestern Cape, South Africa. A, P. obtusifolia; B, P. brachyphylla; C, P. macrantha; D, P. caespitosa.

rarely present; glumes two, more or less equal, $18-60 \mathrm{~mm}$ long, 3-7(-9)-nerved, chartaceous, minutely scabrid or glaucous; lemma body chartaceous to cartilaginous, variously pubescent, $4.5-11.0 \mathrm{~mm}$ long, 7-9-nerved, nerves anastomosing into awn base and 8-27 mm long lateral bristle; lemma lobes $1.5-4.5 \mathrm{~mm}$ long, acute to acuminate, partly to fully adnate to bristles; central awn geniculate, scabrid, contorted basally, 5-17 $\mathrm{mm}$ long from base to knee, 12-34 $\mathrm{mm}$ long from knee to tip; palea longer than lemma body, bifid at apex. Lodicules two, glabrous, sparsely to densely ciliolate. Stamens three, $4.5-9.0 \mathrm{~mm}$ long. Ovary glabrous, with apical pseudostigmata, styles short to absent. Fruit a caryopsis, $4-6 \mathrm{~mm}$ long, hilum $7 / 8$ as long as fruit, embryo $1 / 5$ as long as fruit, surface reticulately sculptured.

Key to species

la Lower glumes 18-25 mm long, 3-nerved basally, central nerve extending the length of glume; lodicules densely ciliolate

1. P. obtusifolia

lb Lower glumes (27-)35-60 mm long and (3-)5-9-nerved; lodicules sparsely ciliolate or glabrous:

2a Lemmas pubescent over entire abaxial surface . 2. P. brachyphylla

$2 \mathrm{~b}$ Lemmas basally glabrous, apically pubescent, including lemma lobes:

3a Lemma body 5-8 mm long; awn (knee to tip) 11-18 mm long: lemma bristle 9-15 mm long; plants with branched above-ground stems, especially in older plants . . . . . . . . . . . . . . 3. P. macrantha

3b Lemma body 8-10 mm long; awn (knee to tip) 17-27 $\mathrm{mm}$ long; bristle $15-30 \mathrm{~mm}$ long; plants with woody or fibrous underground base, branched above-ground stems absent

4. P. caespitosa

\section{Pseudopentameris obtusifolia (Hochst.) N.P. Barker}

Danthonia obtusifolia Hochst. in Flora 29: 120 (1846); Stapf: 536 (1899). Pentameris obtusifolia (Hochst.) Schweick.: 91 (1938); N.P. Barker in Gibbs Russell et al.: 252 (1990). Type: Pr. b. spei, Ludwig s.n. (OXF, iso.(?)!).
Avena rigida Steud.: 482 (1829), non $A$. rigida M. Bieb. (1808). Danthonia rigida Steud.: 243 (1855). Type: Pr. b. spei, Ludwig s.n. (OXF, holo.! or iso.!).

Pentameris squarrosa Stapf: 515 (1899); Linder \& Ellis: 91-103 (1990). Type: Caledon Div., Nieuw Kloof in Houw Hoek Mountains, Burchell 8076 (K, holo.; PRE, iso.!).

Pentameris sp. nov., Ellis: 567 (1985b); Barker: 136 (1989).

Plants perennial; scandent, sometimes branched. Stems branching, 0.4-1.5(-3.0) $\mathrm{m}$ long, woody and persistent, flowering culms produced annually from apical growth points. Leaves: sheaths appressed to culm, persistent; sheath mouth slightly bearded; leaf blades linear, 25-120 $\mathrm{mm}$ long, somewhat rolled and rigid. Inflorescence paniculate, lanceolate and contracted. Spikelets 8-45, laterally compressed, 2-flowered; glumes two, more or less equal, 18-25 mm long, chartaceous, minutely scabrid, 3-nerved basally, central nerve extending to glume apex; lemma body uniformly pubescent, 4.5-6.0 mm long, 9-nerved, nerves anastomosing into awn base and a 8-12 $\mathrm{mm}$ long lateral bristle; lemma lobes $1.5-3.0 \mathrm{~mm}$ long, acute to acuminate, partly to fully adnate to bristles; central awn geniculate, scabrid, contorted basally, 7.5-11.0 mm long from base to knee, $12-16 \mathrm{~mm}$ long from knee to tip; palea longer than lemma body, bifid at apex. Lodicules two, densely ciliolate, cilia as long as lodicule body. Stamens three, 4.5-7.5 mm long. Ovary glabrous, with apical pseudostigmata, styles short to absent. Fruit $4 \mathrm{~mm}$ long. Flowering time November to January. The known distribution of this species is indicated in Figure $3 \mathrm{~A}$.

Schweickerdt (1938) points out that Steudel (1829) and Hochstetter (1846) probably described new taxa from duplicate material collected by Baron von Ludwig. Hochstetter called his species Danthonia obtusifolia Hochst., whereas Steudel named the material Avena rigida Steud. Schweickendt showed that the name Avena rigida had been used earlier by Marschall von Bieberstein (1808) and therefore Steudel's later homonym is rejected. The Ludwig specimen at OXF bean the name Avena rigida, and is considered to be the 
holotype or perhaps an isotype of this name. The specimen seen by Hochstetter was not traced, so the same specimen (Ludwig specimen at OXF) is considered to be probably the isotype of the name Danthonia obtusifolia. Hochstetter's (1846) D. obtusifolia has priority over Stapf's (1897) $D$. squarrosa. Schweickerdt notes that had Stapt seen the type material on which Steudel had based his description. he would have been able to identify his species as Damthonia oblusifolia Hochst.

The type of Stapf's Pentameris squarrosa is a Burchell specimen. Burchell 8076. There is a fragment of this specimen in PRE, which originates from Kew. The envelope is annotated by Schweickerdt. who wrote 'a fair match of the type of Avena rigida Steud. in the Herb. Fielding. Oxford'. This fragment, consisting of two leaves and two spikelets, comprises sufficient material to allow comparison on the basis of a number of characters. It is a good match of the type specimen of Alena rigida. It can therefore be confirmed that Pentameris squarrosa is a synonym of Pseudopentameris obtusifolia.

This nomenclatural confusion is reflected in past studies and curatorial practices (cited above). The use of these confusing names without voucher citations in red data books (e.g. Hall et al. 1980) results in further confusion and renders the information in such texts meaningless. In order to assist in the identification and curation of specimens of this taxon, an extended list of voucher specimens is provided. The herbarium code JF is used for the herbarium at Jonkerhoek Forestry Station.

Vouchers: N. Barker 300), 331, 332. 333 (PRE): Burchell 8076 (PRE): Ellis 2342 (PRE): Esterhuisen 29029, 35396 (BOL. PRE): Esterhusen 35416 (BOL): Havnes 770 (JF. PRE. STE): Hilton-Tavlor 350, 351, 352. 353 (PRE); Kruger KR565 (JF): Levins 10460) (BOL); Macdonald 634 (PRE. STE): Stokse 7197 (BOL): Tavlor 3023 (PRE. STE).

2. Pseudopentameris brachyphylla (Stapf) Conert in Mitteilungen der Botanischen Staatssammlung. München 10: 304 (1971): N.P. Barker in Gibbs Russell et al. 278 (1990). Type: Locality unknown. Zevher $1826 \alpha$ (K. holo.!).

\section{Danthonia brachyphylla Stapf: 520 (1899).}

Plants perennial. caespitose, bases woody and fibrous Stems absent. Culms 4() $-750 \mathrm{~mm}$ long. Leaves: sheaths appressed to culm. persistent; sheath mouth slightly auriculate: leaf blades $45-150 \mathrm{~mm}$ long, open and flat or folded. Inflorescence paniculate, lanceolate and con tracted. Spikelets 8-20, laterally compressed, 2-flowered. highly reduced third floret rarely present; glumes two, more or less equal, 27-37 mm long. 5-7-nerved, chartaceous. minutely scabrid: lemma body cartilaginous. uniformly pubescent, 5.5-6.5 mm long, 7-9-nerved, nerves anastomosing into awn base and $12-20 \mathrm{~mm}$ long lateral bristle: lemma lobes $2.0-3.5 \mathrm{~mm}$ long. acute to acuminate, partly to completely adnate to bristles; central awn geniculate, scabrid. contorted basally, 7.5-11.0 mm long from base to knee, $12-20 \mathrm{~mm}$ long from knee to tip; palea longer than lemma body. bifid at apex. Lodicules two. glabrous or sparsely ciliolate. Stamens three, 5-8 mm long. Ovan glabrous, with apical pseudostigmata, styles short to absent. Fruit $4.5-6 .() \mathrm{mm}$ long. Flowering time
September-October. The distribution of this species is given in Figure 3B.

The holotype, Zeyher $1826 \alpha$ housed at Kew is accompanied by drawings and annotations in Stapf"s hand. Conert (1971) also cites this specimen, and it carries a det. slip' bearing his signature. Although the type locality is not known, PRE has a Zeyher collection of the same taxon. Zeyher 1825ß. collected at Hemel en Aarde, Swellendam. Although speculative, it is possible that these consecutively numbered Zeyher specimens were both collected from this locality.

Vouchers: N. Barker 73/ (PRE): Burman 1/80) (BOL); De Vos 1+()/ (STE): Esterhuwsen 33258 (BOL, PRE); Williams 2542 (NBG, PRE).

3. Pseudopentameris macrantha (Schrad). Comert in Mitteilungen der Botanischen Staatssammlung. München 10: 304 (1971): N.P. Barker in Gibbs Russell et al. 279 (1990). Type: Table Mountain above Kirstenbosch, White 5518 (PRE, neo.! here designated).

Damthomia macrantha Schrad. in J.A. Schultes: 385 (1824); Trinius: 1. 63 (1827); Penameris macrantha (Schrad.) Nees: 312 (1832). Type: P.B.S., Hesse, s.n. (not traced).

Plants perennial, basally woody, caespitose, becoming shrub-like with age. Stems branched, 0.5-1.4 m long, covered in persistent leaf sheaths. Culms $0.5-0.8 \mathrm{~m}$ long. Leaves: sheaths appressed to culm, persistent; sheath mouth somewhat auriculate; leaf blades $45-350 \mathrm{~mm}$ long. open and flat or rolled and filiform. Inflorescence paniculate, lanceolate and somewhat contracted. Spikelets 10-25(-50), laterally compressed, 2-flowered, highly reduced third floret rarely present; glumes two, more or less equal. chartaceous, minutely scabrid or glaucous, 22-50) mm long, 5(-7)-nerved: lemma body cartilaginous, apically pubescent, basally glabrous, 5-8 mm long, 9-11nerved. nerves anastomosing into awn base and 9-15 mm long lateral bristle; lemma lobes $1.5-3.5 \mathrm{~mm}$ long, acute to acuminate, partly to fully adnate to bristles; central awn geniculate, scabrid. contorted basally, 5.5-11.0 mm long from base to knee, $11-18 \mathrm{~mm}$ long from knee to tip: palea longer than lemma body, bifid at apex. Lodicules two, glabrous or sparsely ciliolate. Stamens three, $5.0-7.5 \mathrm{~mm}$ long. Ovary glabrous. with apical pseudostigmata, styles short to absent. Fruit $4.5-6.0 \mathrm{~mm}$ long. Flowering time August to September. The distribution of this species is shown in Figure 3C.

Conert (1971) combined Pentameris macramtha Nees and Danthomia macrantha Schrad. The Hesse s.n. specimen on which Schrader (1824) based his original description of Danthonia macrantha has not been traced, and it is not known if this specimen was seen by Conert (1971) A neotype is designated here in its place.

The absence of a type specimen, and thus accurate tloral measurement data. caused some problems in the allocation of the epithet macramtha to the relevant cluster in the PCA study. Despite the lack of the type specimen. Schrader's (1824) description includes the spikelet length. given as 1.5 inches $(37.5 \mathrm{~mm})$. As the glumes extend well beyond any floret parts except the awns. this spikelet measurement is interpreted to equate to that of the glumes. As this figure $(37.5 \mathrm{~mm})$ is close to the mean glume size 
$(37.14 \mathrm{~mm})$ for one of the two clusters distinguished by the PCA. this cluster is allocated the epithet macrantha (Figure 1).

In contrast to the paucity of information provided by Schrader. Trinius (1827) provides an elegant description of this species. referring to an elongate woody rhizome and a branched culm. This description is accompanied by a detailed illustration showing a well-developed rhizome. These characters clearly match the morphology of the specimens in the rhizomatous cluster of the PCA, which Schrader's description implies represents $P$. macrantha. Unfortunately, although citing Schrader's description. Trinius does not provide a collector and number for the specimen on which his description or illustration is based. and mentions no type specimen. Therefore the link between his clear description and the Hesse specimen on which Schrader's description was based is tenuous at best.

The Trinius herbarium is presently housed at St Petersburg (Leningrad). The grass collection. including Trinius"s types and the material on which his illustrations are based. have recently been databased ( $R$. Soreng. Comell University pers. comm). Computer records indicate that these include several specimens of Damthonia macrantha. although the type status of these is not certain. All attempts to communicate with this herbarium have failed, and thus the unsatisfactory solution of neotypification has been implemented. The second cluster in the PCA is considered to be a neu species and is described below.

Vouchers: Adamson 125/ (BOL); Boncher 266/ (STE): Ellis 2308 (PRE): Morely 176 (STE): White 5518 (PRE).

4. Pseudopentameris caespitosa N.P. Barker sp. nov. a $P$. macrantha habitu caespitoso, culmis simplicibus, partibus floralibus grandioribus, glumis $33-60 \mathrm{~mm}$ longis. arista centrali lemmatis $27-45 \mathrm{~mm}$ longa differt

Plants perennial with woody or tibrous basal underground parts. caespitose. Stems absent. Culms annual. 0.7-1.0 $\mathrm{m}$ long, sometimes decumbent. Leaves: sheaths basal. persistent. often purple. appressed to culm: sheath mouth somewhat auriculate: leaf blades $45-500 \mathrm{~mm}$ long. open and that or rolled. Inflorescence paniculate. lanceolate and contracted, upper culm and panicle branches purple. Spikelets 10-20. laterally compressed. 2-flowered. highly reduced third floret rarely present: glumes two. more or less equal. 33-60 $\mathrm{mm}$ long. 5-9-nerved. chartaceous, minutely scabrid or glaucous. dark purple when young: lemma body cartilaginous. apically pubescent. basally glabrous. $8-10 \mathrm{~mm}$ long. 9-11-nerved. nerves anastomosing into awn base and $1.5-30 \mathrm{~mm}$ long lateral bristle: le'mma lobes $2-4 \mathrm{~mm}$ long. acute to acuminate. partly to fully adnate to bristles: central awn geniculate. scabrid. contoned basally. $10-18 \mathrm{~mm}$ long from base to knee, 17-27 mm long from knee to tip: palea longer than lemma body, bifid at apex. Lodicules two. glabrous or sparsely ciliolate. Stamens three. up $109 \mathrm{~mm}$ long. Ovar glabrous, with apical pecudostigmata. styles short to absent. Fruit 5 -6 mm long. Flowering time Octoher-November. The known distribution of this species is shown in Figure 3D.
TYPE.-Western Cape, 3419 (Caledon): Bredasdorp. (-DC), eastern corner of Farm Buffeljagt, 19-10-1987. Linder 4362 (BOL. holo.!).

This species is characterised by both its larger floral structures and its caespitose. unbranched growth form. hence the specific epithet. The glumes, culms and panicle branches are often dark purple when young, turning a dark brown hiscuit colour with age. in comparison to the pale yellow of the glumes of $P$. macramtha. Although occurring with $P$. macrantha in some localities (e.g. Cape Point Nature Reserve, where they have been observed growing within a metre of each other). $P$. caespitosa flowers substantially later than $P$. macramtha. thus precluding any possible hybridisation.

In addition to the morphological differences described above. certain differences in the leaf anatomy have also been observed. In a phenetic study on a limited number of anatomical samples. Barker (1990) noted that specimens of what was then named $P$. macramtha were separable into two groups on the basis of three anatomical characters. One of these groups corresponds to the taxon here named $P$. macrantha and has a leaf which is $\mathrm{V}$-shaped in cross section. with narrow furrows between the ribs and prickles distributed over the exposed adaxial rib surface. The other group corresponds to $P$. caespitosa (described above) in which the leaf is $\mathrm{U}$-shaped. the furrows are open and the prickles are restricted to the edges of the adaxial ribs.

Vouchers: N. Barker 24 (PRE): Boucher \& Shepard 482l (STE); Ellis 1/71. 2515 (PRI): Esterhusen 31747 (BOL).

\section{ACKNOWLEDGEMENTS}

I would like to extend my thanks and appreciation to Mrs A. Romanowski (National Botanical Institute. Pretoria) and R. Carelse (University of Cape Town) for the photographic work. Dr J. Rourke (NBI. Kirstenbosch) for the Latin translation and nomenclatural advice. Drs E.R. Robinson (University of the Witwatersrand). R.P. Ellis (Roodeplaat Grasslands Institute). and Prof. H.P. Linder (University of Cape Town) for their comments on various aspects of this work. The curators of B. BOL. G, GRA. K. NBG. OXF: PH. PRE. S. SAM and STE are thanked for assisting in the tracing and loan of type material. Most of this work was undertaken for an M.Sc. study at the University of the Witwatersrand. and was carried out while the author was in the employ of the National Botanical Institute. Pretoria

\section{REFTRENCES}

BARKER. N.P. 1986. The shape and ultrastructure of the caryopsis of Pensumeris and Pseludopentameris species (Arundinoideate. Poaceace. Bothulia 16: 65-69

BARKER. N.P. 1989. The caryopsis surface of Pentameris and Presadopensameris (Arundinordeac. Poaceace) revisited. Borhalia 19: $134-136$

BARKER. N.' 19y). The faxonom of Pentameris $P$. Bealus and Preudopentameris Comern. M.Sc. thesis. University of the Witwatersiand.

BARKER. NP 1943. A bionvisematic studs of the genus Pentameris (Arundinease. Pouceale). Bothalia 23: $25-47$.

BARKER. NP 1994 External fruit momphology of wothern African

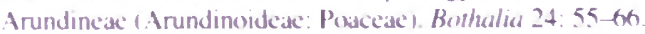


BARKER, N.P. \& ELLIS, R.P. 1991. A new species of Merxmueller (Arundinoideae, Poaceae) from South Africa. Bothalia 21: 27-34.

BOND, P. \& GOLDBLATT, P. 1984. Plants of the Cape Flora. A descrip tive catalogue. Joumal of South African Botany Supplementary Vol. 13: 1-455.

CHIPPINDALL. L.K.A. 1955. A guide to the identification of grasses in southern Africa. In D. Meredith, The grasses and pastures of South Africa. Central News Agency, Cape Town.

CLAYTON, W.D. \& RENVOIZE, S.A. 1986. Genera graminum. Grasses of the World. Her Majesty's Stationery Office. London.

CONERT, H.J. 1971. The genus Danthonia in Africa. Mitteilungen der Botanischen Staatssammlung, München 10: 299-308.

DE WET. J.M.J. 1953. Nucleoli numbers in Danthonia polyploids. $C y$ tologia 18: 229-234

DE WET, J.M.J. 1954a. Stomatal size as a cytological criterion in Danthonia. Cytologia 19: 176-181.

DE WET. J.M.J. 1954b. The genus Danthonia in grass phylogeny. American Joumal of Botany 41: 204-211.

DE WET. J.M.J. 1956. Leaf anatomy and phylogeny in the tribe Danthonieae. American Journal of Botany 43: 175-182

DE WET, J.M.J. 1960. Leaf anatomy and morphology in South African species of Danthonia. Bothalia 7: 303-310.

DU PLESSIS. H. \& SPIES, J.J. 1988. Chromosome studies on African plants. 8. Bothalia 18: 119-122.

ELLIS. R.P. 1985a. Leaf anatomy of the South African Danthonieade (Poaceae). X. Pseudopentameris. Bothalia 15: 56 I-566.

ELLIS. R.P. 1985b. Leaf anatomy of the South African Danthonieac (Poaceae). XI. Pentameris longiglumis and Pentameris sp. nov. Bothalia 15: 567-571.

ELLIS, R.P. \& LINDER, H.P. 1992. Atlas of the leaf anatomy in Pentaschistis (Arundineae: Poaceae). Memoirs of the Botanical Survey of South Africa No. 60.

GIBBS RUSSELL. G.E., WATSON, L., KOEKEMOER, M., SMOOK. L., BARKER. N.P., ANDERSON, H.M. \& DALLWITZ, M.J. 1990. Grasses of southern Africa. Memoirs of the Botanical Survey of South Africa No. 58.

HALL, A.V., DE WINTER, M.. DE WINTER, B. \& VAN OOSTERHOUT, S.A.M. 1980. Threatened plants of southern Africa. South
African National Scientific Programmes Report No. 45. CSIR Pretoria.

HOCHSTETTER, C.H. 1846. Pflanzen des Cap- und Natal-landes, gesammelt und zusammengestellt van Dr. Ferdinand Krauss. Flor 29: 113-128.

LINDER. H.P. \& ELLIS. R.P. 1990). Vegetative morphology and interfire survival strategies in the Cape Fynbos grasses. Bothalia 20: 91-103.

MARSCHALL VON BIEBERSTEIN, F.A. 1808. Flora taurico-cau casica. Vol. 1. Charkow.

NEES AB ESSENBECK. C.G. 1832. Plantae Ecklonianae. Linnaea 7 273-339.

RENVOIZE, S.A. 1981. The subfamily Arundinoideae and its position in relation to a general classification of the Gramineac. Kew Bulletin 36: $85-102$

RENVOIZE, S.A. 1986. A survey of leaf blade anatomy in grasses VIII. Arundinoideae. Ken Bulletin 41: 323-338

ROHLF, F.J. 1988. NTSYS-pc. Numerical taxonomy and multivariate analysis system. Exeter Publishing, Setauke, New York.

SCHULTES J.A. 1824. Mantissa plantarum 2. In J.J. Roemer \& J.A Schultes, Systematis vegetabilium Caroli a Linné. Stuttgart.

SCHWEICKERDT. H.G. 1938. Dexcriptions and notes on South African grasses. Feddes Repertorium 43: 88-92.

SPIES, J.J. \& DU PLESSIS, H. 1988. Chromosome studies on African plants. 6. Bothalia 18: 111-114.

SPIES. J.J., DU PLESSIS, H., BARKER, N.P. \& VAN WYK. C. 1990. Cytogenetic studies in the genus Chaetohromus (Poaceac: Arund ineae). Genome 33: 646-658.

STAPF, O. 1899. Gramineac. Flora capensis 7. Reeve. London.

STEUDEL. E.G. 1829. Bemerkungen ueber einige Cyperaceen und Gramineen vom Vorgebirge der guten Hoffnung. Flora 12: 481-492.

STEUDEL, E.G. 1855. Synopsis plantarum graminearum. Metzler, Stuttgar.

TOMLINSON, K.L. 1985. Comparative anatomical studies in Damthonic sensu lato (Danthonieae: Poaceae.). Aliso 11: 97-114.

TRINIUS, C.B. 1827. Species graminum 6: t. 63. Petropoli. 